Оливера В. РАДУЛОВИЋ ${ }^{*}$ Универзитет у Новом Саду Филозофски факултет
Оригинални научни рад

Примљен: 09. 12. 2019.

Прихваћен: 12. 02. 2020.

\title{
РАЈСКА ЛЕСТВИЦА СВЕТОГ ЈОВАНА ЛЕСТВИЧНИКА У ТУМАЧЕЊИМА ВЛАДЕТЕ ЈЕРОТИЋА*
}

\begin{abstract}
Премиса овог истраживања је да Рајска лествица Светог Јована Лествичника, светитеља цркве из VI и VII века, игумана Синајске горе и једног од највећих аскетских писаца, надахнута сном јеврејског праоца Јакова (Пост. 28, 12-13) - пресудно утиче на савремену српску православну духовну мисао, те да се находи у подтексту есеја савремених српских писаца као што су Миодраг Павловић и Момчило Настасијевић. Циљ истраживања је да аналитички образложи постављену тезу, те да нагласи да и данас жива идеја богонадахнутих људи о ступњевитом узрастању на путу ка савршенству сугерише динамизам хришћанске духовности и служи повезивању етичких, естетичких и поетичких ставова српских писаца, махом есејиста и песника. Исто тако, намера истраживача је да укаже на значај Владете Јеротића као ванредног тумача православне мисли и као популаризатора и преносиоца њених идеја. Наиме, Владета Јеротић је Рајску лествицу Светог Јована Лествичника довео у присан дијалог са искуством савременог човека који трага за идентитетом и духовношћу, учинивши је при томе својим коментарима савременом.

Кључне речи: Рајска лествииа, Свети Јован Лествичник, духовност, ступњевито узрастање, светоотачки етос, православни менталитет, обожење.
\end{abstract}

1. Трилогија Владете Јеротића Повратак оциима, чији је наслов у знаку максиме Георгија Флоровског, теолога XX века, подсећа нас на значај светоотачког етоса у нашем времену. Велики српски духовник и академик, професор Теолошког факултета у Београду, психијатар и психотерапеут, у поменутој књизи обједињује студије о тројици светитеља: Јовану Лествичнику, Исаку Сирину и Максиму Исповеднику, те се са њиховим учењима сусреће на егзистенцијалном плану и њихово духовно искуство доводи у везу са проблемима човека нашег времена. Величина подухвата Владете Јеротића, који својом делатношћу подсећа на древне апостоле, тумаче Светог писма, у томе је што је пронашао духовно врело православне мисли у далекој прошлости усагласивши га са достигнућима савремене медицине, особито пси-

*oliveraradulovic.ff@gmail.com

** Овај рад представља део истраживања у оквиру пројекта, који финансира Министарство просвете, науке и технолошког развоја Републике Србије. 
хијатрије и психотерапије. „Помоћу вере, која даје егзистентност духовном и омогућује трансценденцију овоземаљског, он је остварио синтезу и винуо се до духовних висина које зрачећи истином непосредног искуства делују животно, подстицајно и исцељујуће" (Јовић 2008: 22). Јеротић, попут ренесансних мислилаца, суверено отвара мноштво тема из различитих области науке, води читаоца кроз медицину и њену историју, психијатрију, психологију, историју религије и културе, историју цркве, теологију и патрологију. Тако он у својим интердисциплинарним студијама проводи дубинско истраживање српског православног менталитета и културе.

Учење Светога Јована Лествичника и наше време збирка је од шест есеја коју је Владета Јеротић објавио 1996. године. У уводу академик Јеротић указује на то да се Свети Јован Лествичник са 16 година замонашио у Синајском манастиру (од IX века познатом као манастир Свете Екатарине), месту које је, захваљујући величини своје светости, постало средиште духовног живота и стециште монаха из Египта и Палестине. Свети Јован је ту живео пуних 19 година под духовним менторством старца Мартирија да би се после његове смрти повукао у пећину на месту званом Тола, где подвижнички обитава још пуних 40 година. Његови светачки подвизи окупљају монахе који га посећују ради поучења и исцељења. Своју испосницу напустио је на десетак година, вероватно почетком 600. године, да би обављао дужност игумана, коју је пред смрт уступио брату Георгију да би умро у смирењу у својој испосници у Толи. Лествичник је, према његовом животопису који је написао монах раитски Данило, био веома образован човек, који је, поред доброг познавања Светог писма и светоотачке литературе, знао и класичну филозофију и медицину. Димитрије Богдановић наводи да је Лествичник у своје време био веома поштован као духовник и посвећеник у свевишње тајне, те као аргумент тој тврдњи наводи писмо упућено Светом Јовану од стране Јована Раитског, игумана другог синајског манастира, у коме га овај саветује да напише дело посвећено монашком животу и монашкој филозофији (Богдановић 1997: 7-8). Тако је, на подстицај брата у вери, настала Лествица, односно Рајска лествица, најпознатија творевина великог светитеља, по којој је он и назван Лествичник.

Идеја овога дела је ступњевито узрастање у духовном живљењу и означава човеково узношење ка небу и Божјем савршенству, током којег се он ослобађа земаљских стега. Јеротић у форми дијалога, речју отворен за искуство синајског монаха, наглашава значај хришћанског пута ка истинитом и здравом животу као подвиг у виду 30 ступњева узрастања у духовном савршенству, подвиг који води излечењу, очишћењу и уцеловљењу живота. Поента рада посвећеног Рајској лествици Светог Јована Лествичника, јесте пети есеј насловљен „О појму напредовања у православљу”, који осветљава и тему стваралаштва у контексту идеје обожења и индивидуације. Владета Јеротић изражава уверење да сва духовна бића током живота расту из славе у славу, из знања у знање, а сва достигнућа духовног живљења добијају истинско озарење од Светог духа, стога предлаже - надахнут ставовима Светога Јована Лествичника и присећајући се Поуке I из Рајске лествице - да мо- 
нахом (монахос 'јединствен, изврстан') назовемо свако биће које тежи обожењу. „Који је монах вредан и паметан? Онај који је сачувао своју ватреност и који свакога дана, до краја свога живота, није пропуштао да дода пламен на пламен, жар на жар, ревност на ревност и чежњи за Богом, богочежњивост?" (Јеротић 2017: 97). Јеротић, у контексту напред реченог, како видимо, верује у универзалност Лествичниковог дела и животност његових идеја, његову примену и у наше време, у еволуцију добра у човеку, коју замишља као спирално путовање, са успонима, падовима и странпутицама. Ту аутор рада Свети Јован Лествичник и наше време наглашава значајну разлику између човека-монаха, који цео живот развија своја крила припремајући их за узлет, и оног човека који није монах и који у овоземаљском забрану животни век проводи окован материјалношћу. Потцртавајући Лествичникове речи да човек на путу духовног узрастања не треба да се осврће, већ да се учврсти у вери постигавши одговарајући степен душевно-духовног зрења - присећа се Спаситељевих речи из Јеванђеља по Луки: „Ни један није приправан за царство Божје који метне руку своју на плуг, па се обазире натраг” (Лука 9, 62).

Вера, милосрђе и покајање су, према Јеротићевим тумачењима, предуслов за изградњу зреле религиозне личности. Међутим, ниједно од та три није лако учинити, а нарочито не покајати се, јер је покајање најтеже, што Јеротић формулише на следећи начин:

„Кајање је света јорданска вода која све чисти: грехе наших родитеља којима после кајања опраштамо бремена којима су нас, много више невољно него вољно, од раног нашег детињства оптеретили, као и наше сопствене грехе из прошлости којих се мучно и болно, али све тачније и прецизније сећамо” (Јеротић 2017: 105).

Свети Јован Лествичник у Поуци XV налази да људска природа не може да победи себе и кад год човек начини подвиг, препознаје се долазак Онога који је изнад природе, а освртање на грешну прошлост ваља заменити живим сећањем на Божју Благодат. Јеротић наглашава да постоји појачана свест покајаног човека о потреби одбацивања греха и ту доводи у везу патристику и савремену психологију: појачана интроспекција, свест о сопственим манама и гресима - речју, јачање контроле над душевним и духовним збивањима - омогућују подвижнику доживљај духовног напретка, чији је циљ да постане Божји сарадник на делу борбе против зла у свету. Аутор, као аргумент властитим напред изнетим ставовима, позива у помоћ њему толико блиског руског филозофа Николаја Берђајева: „Иза овог прага већ се збива спасење као одлучно самоопредељење и започиње благодатно растење за сваког човека према његовом лику и типу духовне активности. Светост је исто толико разноврсна као и људске индивидуалности" (Берђајев, Православље, Нови Сад, 1991).

Владета Јеротић указује на особеност благодатног растења на хришћанском путу, и примећује да би духовници као и психотерапеути требало да познају типологију личности. У помоћ опет позива Светог Јована Лествичника, који разликује два типа личности: чисте и скромне, склоне уздржавању, кротке по природи, и оне чија се природа противи врлинама, па воде 
непрекидан рат са собом, које, међутим, Јеротић похваљује због тежине препрека које се јављају на њиховом успињању. На овом месту у есеју на снази је инвентивна максима из XXVI поуке: „Оно што је за једнога лек, за другога је отров. А понекад једна иста ствар једном те истом човеку, када се даје у прикладно време, служи као лек, а када се даје у неодговарајуће време, делује као отров [...] Много је путева побожности, као што је много путева пропасти. Зато се често дешава да онај пут који је за једног човека добар, другоме не одговара, а намера и једног и другог човека је угодна Господу" (Јеротић 2017: 111). Аутор књиге Повратак оцима поставља питање: Зашто је потребно да хришћанин напредује?, при чему одговара метафоричним језиком апостола Павла: „Зато, ако је ко у Христу, нова је твар: старо прође, гле, све ново постаде” (Кор. 2, 5: 17) и сугерише да Спаситељ позива човека на преображај. Подсећајући нас на речи Светог Атанасија Великог: „Бог је постао човек да би човек могао да постане Бог”, Јеротић разматра различите термине који указују на исту појаву којом се бави Рајска лествица: обожење, доживотно напредовање, индивидуација, који се користе у различитим областима науке, а заправо имају сродна значења. Сећајући се Химне љубави апостола Павла, Јеротић поентира да је човек испуњен хришћанском вером и надом, отворен према љубави чији је извор љубав Божја, која никада не престаје. Тако смо на трагу уверења Светог Јована Лествичника да духовна бића свагда напредују, реч је и о њиховом оностраном напретку.

У Закључку овога есеја аутор налази да је Свети Јован Лествичник боље познавао људску душу од било ког психолога, а то познавање је последица узрастања у подвижничком хришћанском животу, доказ његове интуитивности и ширине ума, који су дарови Духа Светог.

2. Аутор књиге Свети Јован Лествичник и наше време бави се у другом есеју и односом хришћанске вере и људске природе, опет наводећи речи Светога: „Бог није створио ни начинио зло. Стога су у заблуди извесни људи који тврде да су неке страсти у људској души природне. Они не знају да смо ми позитивна својства душе претворили у страсти” (Јеротић 2017: 84). Јеротић поставља увек живо питање шта је људска природа и какав је однос хришћанске вере према људској природи, откривши да не налазимо задовољавајуће одговоре јер је човек велика тајна као телесно, душевно и духовно биће. Констатује да су на ово питање различито одговарали први филозофи и религиозни мислиоци и тим поводом помиње учење питагорејаца, орфичара и Платона, који пресудно утичу на рано хришћанство и аскетску литературу, о телу као тамници душе у којој она бива кажњена верујући да се душа прочишћава у току поновљених живота да би се бесмртна вратила својој прапостојбини. Док је Платон био уверен да се човек састоји од пропадљивог тела и вечне и бесмртне душе, Аристотел је веровао да постоје три врсте душе које оживљавају тело и чија је судбина неизвесна. Хришћанска струја изнедрена из јудаизма коју је заступао Свети Макарије Велики - сматрала је да је васкрсење могуће у јединству преображеног тела, душе и духа, што је рекао и апостол Павле у Првој посланици Коринћанима: „Или не знате да је тело ваше храм Светога Духа који је у вама, којега имате од Бога и 
нисте своји? Јер сте купљени скупо. Прославите, дакле, Бога телом својим и духом својим јер су Божји" (Кор. 1, 6: 19, 20). Јеротић поставља питање одакле у људима нагони, тим бићима створеним на врхунцу стваралаштва из добре намере, бићима која је Бог створио из праха земаљског и удахнуо им свој дух. Материјализму окренути научници тврде да је човек током своје еволуције оставио провалију између природног и цивилизацијски културног живота и да је управо тај јаз одговоран за сукобе, ратове и болести. „Човек плаћа неразрешив сукоб душе и тела, душе и духа нелагодностима у култури, неурозама, психозама и ратовима" (Јеротић 2017: 83). Аутор уприличује својеврсан дијалог између светоотачке литературе и науке констатујући да су људске страсти природно гориво које они могу трошити на добро или на зло. Напослетку Јеротић поставља опет реторско питање да ли је могуће мењати људску природу хришћанском вером. Одговор налази у Поуци XXVI у Лествици: „Поука и навике и читаво васпитање које смо добили у детињству помажу нам или нас ометају, кад одрастемо, у постизању врлина и монашком животу" (Јеротић 2017: 88). Хришћани знају да је усавршавање и преображавање неопходно за спасење. „Признај пред Господом немоћ своје природе, потпуно свестан своје неспособности, па ћеш неосетно добити дар целомудрености" (исто). Целокупна хришћанска култура и уметност сведоче о стравичној борби добра и зла у човеку, као и о неизвесности те борбе о којој је писао Свети Јован Лествичник: „Како да убијем оно што са мном треба да васкрсне? Како да начиним непропадљивим оно што је добило пропадљиву природу? Какав разлог да наведем ономе који ми може узвратити толиким природним разлозима? [...] Ако га злостављам - и сам се излажем опасности. Ако га упропастим - немам с киме да стичем врлине. Гадим га се - и грлим га. Каква је то тајна са мном? Какав је смисао оваквог устројства мог? Како сам ја самом себи постао непријатељ и пријатељ?! Реци ми, реци ми, о моја супруго, природо моја! Никога другог нећу да питам о ономе што је у вези с тобом. Како да останем неповређен од тебе? Како да избегнем природну опасност, када сам обећао Христу да ћу водити рат с тобом? Како да победим твоју тиранију, када сам добровољно решио да те силом савладам?” (исто).

3. Владета Јеротић се у есеју Јаковљеве лестве (Јеротић 2009: 75-81) враћа теми духовног развоја или обожења, која је надахнула и Светог Јована Лествичника, указујући на Јаковљев сан описан у Првој књизи Мојсијевој из Старог завета, у повести о јеврејском праоцу Јакову, који се, у потрази за обећаном земљом и заштићеним местом где ће јеврејски народ живети слободно, обрео у пустињи, тј, метафорично речено, у обездуховљеном простору. И дође на једно мјесто, и онде заноћи, јер сунце бјеше зашло; и узе камен на оном мјесту, и метну га себи под главу, и заспи на оном мјесту. Иусни, а то љестве стајаху на земљи а врхом тицијаху у небо, и гле, анђели Божји по вима се пењаху и силажаху; и гле, на врху стајаше Господ... ${ }^{1}$ (Прва књига Мојсијева, 28, 11-13). Поводом визије јеврејског праоца о којој је Свети Јован Лествичник писао у делу Лествища, Јеротић је, коментаришући

\footnotetext{
${ }^{1}$ Текст нагласила О. Р.
} 
универзалност симболичке слике, сведочио да су древни народи веровали у могућност исконског додира неба и земље, а духовни свет доживљавали као посве реалан. Остаци овог веровања су визије и архетипски снови, сматра он, као што је био и Јаковљев сан о рајским лествицама. Потом наглашава универзалност симбола лествице у различитим културама, те хришћанско обогаћење овог појма, указујући при томе на дело Светог Јована Лествичника Рајска лествица, које подучава о постојању 30 лествица, својеврсних поука помоћу којих човек може да пронађе пут до неба. Тридесет лествица, објашњава Јеротић, могу да значе 30 година подвижничког живота, али и 30 еона после смрти самопрегорног човека који је уронио у вечност. Речју, опредељење за пут по вертикали мора бити засновано на слободи избора, са пуном свешћу да је духовно сазрео хришћанин вечити ходочасник који се спремно носи са изазовима успона, не само вером у могућност обожења него и свесним избором егзистенцијалне ситуације: човек на путу. Овај је есеј, заправо, сабирно сочиво у ком се преламају естетички и поетички ставови Исидоре Секулић, Момчила Настасијевића и Миодрага Павловића у метафоричној праслици лествица које дотичу небо, а драгоцен је због тумачења архетипског сна јеврејског праоца у ком је визија стваралачке будућности човечанства. ${ }^{2}$ Тема лествица се јавља и у египатској традицији, будизму, хришћанству и исламу, наглашава Јеротић, потврђујући универзалност идеје која подразумева слободно опредељење за веру као тегобно путовање по вертикали. Говорећи о просветљењу у процесу духовног узрастања, аутор истиче да што је пут напорнији то је радоснији сусрет с анђелима, духовним ободритељима из Јаковљеве визије. Миодраг Павловић, размишљајући о динамици православне духовности, наводи пример високих идеала у стваралаштву православних уметника које запажа у визији речи, речитости слике и беседи која досеже највиши ниво у неизрецивости. „Лествица по којој се примичемо ономе што узмиче, на којој благослов с висина не потире сасвим искушења понорних дубина, главно је уздање да ће се стићи у земљу духовних обећања" (Павловић 1999: 78). Сећајући се Лествице Светог Јована Лествичника, аутор наглашава да се уметник преображава у успону до висине која личи на лебдење, превазилазећи своју телесност, и прожима аутентичном духовношћу дело које ствара. Надовезујући се на речено, Владета Јеротић, у интертекстуалном дијалогу с Павловићем у есеју Јаковљеве лестве, размишља о померању граница живота и пише о обожењу: „Просветљеном човеку у успону, а успон је схваћен као духовни напредак, више није битно да ли ће у овом животу стићи близу врха који је недостижан јер за њега смрт више не постоји" (Јеротић 2009: 77-81).

4. У својој књизи Индивидуачија и (или) обожење Јеротић доводи у везу први психолошки са другим теолошким појмом. Индивидуацију одређује као доживотни процес сазревања и усавршавања човека, који Јунг дефинише као долажење самом себи односно као самореализацију, аутор налази да је

\footnotetext{
${ }^{2}$ Видети више у: Библија у подтексту српског есеја 20. века. Оливера Радуловић. Годишњак Филозофског факултета у Новом Саду, XXXV-2, 2010, 141-153.
} 
мали број људи који путем индивидуације стиже до себе јер већини породица и друштво намећу норме понашања и мишљења често супротне етици без које нема индивидуације. Аутор књиге даље поставља питање шта спречава човека да напредује и зашто је духовни напредак битан, на које одмах сам даје одговор: „Зато што једино духовно напредовање човеково, његов незаустављив ход према савршенству, на који му је указао пре две хиљаде година Богочовек Исус Христос може да задовољи и испуни целог човека, што значи, његово телесно, душевно и духовно биће, или његове физичке, емотивне и интелектуалне потребе" (Јеротић 2002: 82). Потом се бави појмом обожења (theozis), које је циљ православног живота у чијем средишту је Бог као личност и човек, констатујући при томе да ни јелинска ни римска филозофија не долазе до јудео-хришћанског појма личности. Аргумент тврдњи да већ у Мојсијевом петокњижју долази до историјског поистовећења ипостаси (природе, суштине) и просопона (лица личности) налази у Јеховином објављивање себе: Ја сам онај који јесам. „Потенцијално слободан, према Божјем лику сачињен, бесмртан по Божјој благодати, а не по нужности или својој заслузи, хришћански човек се обожује, обоготворава, целог живота својим уздизањем ка Богу и Божјим спуштањем ка њему - увек у слободи човекове одлуке и само у љубави према Богу и људима" (Јеротић 2002 18). Творац је, према православној антропологији, човеку дао велики динамички потенцијал који се испољава кроз могућност бескрајног духовног раста који води обожењу. Прва степеница на том путу је спознаја човека да су слобода и разум дар који треба да користи да би се приближио Богу.

Јеротић се присећа Светог Максима Исповедника, који процес обожења сагледава на три степена развоја: првом практичном, афективном, на ком оздрављују делатне силе душе и који представља очишћење, другом степену, созериатељном, на ком оздрављују човекове сазнајне способности и који представља просвећење те, коначно, на трећем, мистичном, којим се човек успиње до богопознања и доводи до синовства Божјег. Констатујући несагласје међу црквеним оцима по питању човековог савршенства, Владета Јеротић наводи Берђајева, тврдећи да је човек позван да настави Божје стварање, те се обожење може третирати као осми дан стварања. Чврсто остајући при тврдњи да је прави напредак без помоћи Свевишњег непостојан и ограничен, Јеротић тумачи да обожење извире из архетипа оца који је боголикост утиснуо у своју творевину налазећи да је егзистенција верујућих стално пред религиозним искушењима.

Аутор позива у помоћ Светог Исака Сирина, који је живео у седмом веку, и његово размишљање о духовном животу и напредовању човека које замишља ступњевито као покајање, очишћење и савршенство. Под појмом покајање тај свети отац подразумева напуштање грешног живота, под чистотом подразумева милосрђе за сваког живог створа, а под усавршавањем дубину смирења. Напредак на хришћанском путовању је немогућ без искреног покајања и исповедања грехова. „Блажен је човек који познаје своју болест и труди се да је излечи. Јер је то темељ врлине. Колико је неко попустљив према себи, толико заостаје у духовном животу. Колико приморава себе, то- 
лико више напредује у врлини" (Јеротић 2002: 84). На овом месту он подсећа на две змије у срцу савременог човека - гордост и завист - које заустављају духовни напредак и неретко поколебају и најстаменијег у вери.

5. „Ништа с предумишљајем. Почетним откровењем у све нова, и свако да садржи клицу даљњег, да му буде пророчанство, и тако на све дозиве исти одјек да се огласи (Настасијевић 1991: 17).

Владета Јеротић је био и врсни тумач књижевних дела пишући тим поводом патографске студије и психолошке огледе, које је сабрао у књиге под називом Дарови наших рођака (Јеротић 1998), указујући на дело омиљеног му аутора Момчила Настасијевића, коме је увек прилазио на прстима као чуду у нашој књижевности. Тиме је овог великог песника, приповедача и есејисту издвојио као узорног уметника који је тежио обожењу, монаха који се за живота посветио живећи аскетски, који је одисао миром и благошћу прочишћен у стваралаштву, гоњен силином духа у успону ка савршенству, који је знао како са божанством и са божанским да општи. „Када чита Момчила Настасијевића, човек је склон да поверује у душе које су постојале пре рођења, у оно што се доста неодређено назива старост душе" (Јеротић 1998: 139), записао је Јеротић у студији Момчило Настасијевић и његова прича „Запис о даровима моје рођаке Марије". Поетика овог посредника између Бога и универзума, како овај песник назива уметнике, може се метафорично одредити као откровење будући да он пристаје на изазов непрекидног усавршавања у процесу стваралаштва. Овај уметник гесло спајања и мирења препознаје у Богу који обитава у души уметника као начело лепоте, а са оне стране стварности, као тајна. Без уметника би ход човечанства навише био веома спор, а можда и доведен у питање јер он познаје начело изворног стварања као уметност ради људске душе.

Момчило Настасијевић је у српској књижевности један од ретких уметника који је отворено изражавао своја религијска убеђења, за шта је најбољи пример његов есеј $У$ одбрану човека, својеврсни уметников духовни тестамент. Реч је о филозофској, теолошкој и песничкој расправи која говори о појави Исуса Христа као прекретници у историји човечанства јер од њега почиње нова фаза развоја духовности заснована на филозофији љубави која добија свој пуни смисао кроз обожење човека, уподобљавање Сину Божјем и човечјем као оствареном лику човека. „Од Христа наовамо процес човека убрзан је до крајњих граница могућности" (Настасијевић 1991: 74). Настасијевић пише да је хришћанство вратило достојанство човеку и одбранило његово право на слободано опредељење за преображај човека ка чисто људском, што назива испуњењем себе - у чему је и лепота егзистенције. „Силом преображеног себе, и телесно и духовно, више не може учинити преступ ни према себи ни према другоме" (Настасијевић 1991: 74) - записао је песник који верује да својом светињом може просветлити друге и тако палити светла у људским душама. Надаље, писац хришћанство доживљава као непрекинут процес суочавања са собом, нужно прочишћење и прогледавање духовним очима. Јер сва страхота наше неиспуњености мора се обелоданити у смрти... Страшни смисао Христове прераности хоће ли се поклопити 
са још страшнијом наслућеном задоџнелости Његовог другог доласка: да у поновљеном юеговом лику човек магновено спозна сву своју пропаст, кад му више спаса нема (Настасијевић 1991: 76) - пита се поета забринут за судбину човечанства. Прави уметник познаје чудо стварања, уз помоћ Божјег надахнућа, у којем речи једна другу дозивају и откривају, а слика рађа слику. Трагање за коренима и изворима, у духовном и националном смислу, предуслови су уметничке снаге и ширине, јер као што је Творац један - једна је и уметност, а начело целине влада универзумом и само целина спасава.

6. Истраживање је пошло од тезе о незастарелости и свевремености дела Светог Јована Лествичника Рајска лествица и његовом утицају на православну духовну мисао преко тумачења Владете Јеротића у књизи Повратак оцима. Аналитичко усмерење је ишло према есеју „О појму напредовања у православљу" са нагласком да је и данас жива идеја богонадахнутих људи и неких уметника о ступњевитом узрастању на путу ка савршенству, која је изворно старозаветна, преузета из сновиђења праоца Јакова. Аутор наглашава значај хришћанског пута ка истинитом и здравом животу као подвига у виду 30 ступњева узрастања у духовном савршенству и повезује га са ставовима модерне психологије и психотерапије. Проналази и идеју појачане интроспекције код самосвесних људи и спаја покајање са духовним прочишћењем, налазећи да је Свети Јован Лествичник зачетник психологије личности. Владета Јеротић се у другом есеју бави односом хришћанске вере и људске природе и отвара проблем борбе добра и зла у човеку, као и тежине и неизвесности те борбе о којој говори и Свети Јован Лествичник у XXVI поуци. Аналитички пропитивану проблематику нашли смо и у Јеротићевом есеју Јаковљеве лестве, у ком аутор идеју подобија у православљу доводи у везу са животима великих људи и стваралаца уверен да су на путу духовног усавршавања победили смрт. Тема човековог напредовања у књизи Индивидуација u (или) обожење, где опет повезује психологију и теологију са констатацијом да су индивидуација као долажење човека себи и обожење као напредовање према Божјем савршенству - идентични појмови и да су неоствариви без Божје благодати. Истраживање се завршава увидом у студију Запис о даровима моје рођаке Марије, у којој откривамо Момчила Настасијевића као узорног, обоженог аутора, који је будући православни верник довео у везу етику и естетику, идеју лепоте са Богом. Истакнут је значај његовог есеја У одбрану човека, који говори о томе да је Богочовек Исус Христос вратио достојанство и слободу човеку могућношћу човековог развоја и преображаја. Речју, рад Рајска Лествица Светог Јована Лествичника у тумачењима Владете Јеротића поентиран је идејом да је дело великог хришћанског светитеља поучно не само савременом човеку већ и уметницима који превазилазе телесну пропадљивост духовним узлетом. 


\section{ЛИТЕРАТУРА И ИЗВОРИ}

Библија или Свето писмо Старога и Новога Завјета (1993), Превео Стари Завјет Ђура Даничић, Нови Завјет превео Вук Стеф. Караџић, Београд: Британско и инострано библијско друштво.

Брија 1999: Ј. Брија, Речник православне теологије, Превео с румунског епископ источно-амерички Господин Митрофан (Кодић), [2., редиговано изд.], Београд: Хиландарски фонд при Богословском факултету СПЦ.

Делом у времену (2008), Зборник са научног скупа одржаног у Нишу 2004, Београд: Ars libri.

Духовност и образовање (2008), Дијалог са делом Владете Јеротића, Зборник радова са научног скупа одржаног 2005. у САНУ - огранак у Новом Саду, Београд: Ars libri.

Јеротић 1998: В. Јеротић, Дарови наших рођака, Београд: Просвета.

Јеротић 2002: В. Јеротић, Индивидуачија и (или) обожење, Београд: Ars Libri.

Јеротић 2009: В. Јеротић, Есеји, психолошке и религијске теме, Нови Сад: Матица српска.

Јеротић 2017: В. Јеротић, Повратак оцима, Београд: Задужбина Владете Јеротића.

Јовић 2008: Б. Јовић, Јеротићев допринос дубинском тумачењу културе, Делом у времену. Београд, 9-20.

Настасијевић 1991: М. Настасијевић, Есеји, белешке, мисли, Горњи Милановац: Дечје новине, Београд: Српска књижевна задруга.

Православље и уметност: (зборник текстова) (1997), Св. Теодор Студит ... [и др.], Београд: Мисионарски и духовни центар манастира Хиландара „Тројеручица”.

Радуловић 2008: О. Радуловић, Беседа о мисији Владете Јеротића, Духовност и образовање, Београд, 107-117.

Ракић 2004а: Р. Ракић, Библијска енцииклопедија, 1 (А-Л), Србиње: Духовна академија Светог Василија Острошког.

Ракић 2004б: Р. Ракић, Библијска енциклопедија, 2 (љ-Ш), Србиње: Духовна академија Светог Василија Острошког.

Свети Јован Лествичник (1997), Лествища, Манастир Хиландар.

Olivera V. Raduloović

\section{RAJSKA LESTVICA SVETOG JOVANA LESTVICNIKA IN VLADETA JEROTIC'S INTERPRETATIONS}

(Summary)

The premise of this research is Ladder of Divine Ascent by Saint John Climacus the church saint from VI and VII century, the monk of Mount Sinai and one of the greatest ascetic writers, is inspired by the dream of the Jewish forefather, Jacob and as such, crucially influences the contemporary Or- 
thodox spiritual thought and is contingent in the subtext of the essays written by the contemporary Serbian writers such as Miodrag Pavlovic (Orthodox Spirituality and Art). The aim of this research is to analytically explain the set thesis statement and to emphasize that even today the live thought about the progressive ascension towards perfection of God-breathed people suggests the dynamics of Christian spirituality and plays the part in bonding ethical, aesthetic and poetic stances of Serbian authors, primarily essayists and poets. In the same manner, the intent of the researcher is to point out the significance of Vladeta Jerotic, an extraordinary exponent of Orthodox thought and an advocate and interpreter of its ideas. In fact, Vladeta Jerotic brings Rajska Lestvica Svetog Jovana Lestvicnika in a very close dialogue with the experience of a modern man who searches for his identity and spirituality by interweaving his comments and making it up- to- date. 